\title{
TRITANGTU DI BUMIDI KAMPUNG NAGA: Melacak Artefak Sistem Pemerintahan (Sunda)
}

\author{
Oleh Agus Heryana \\ Balai Pelestarian Sejarah dan Nilai Tradisional Bandung \\ Jln. Cinambo No. 136 Ujungberung Bandung \\ Email:agus.yana17@yahoo.co.id \\ Naskah diterima:7 Juni 2010 \\ Naskah disetujui: 6 September 2010
}

\begin{abstract}
Abstrak
Tritangtu di Bumi adalah sistem pemerintahan tradisional di tatar Sunda yang membagi kekuasaan dalam tiga peran yaitu Rama (Tuhan), Prabu (manusia), dan Resi (alam). Keberadaannya masih dapat dilacak di kampung-kampung adat, salah satunya adalah Kampung Naga. Penelitian ini menggunakan metode deskripsi yang mampu menjelaskan secara rinci perihal perikehidupan masyarakat Kampung Naga. Di samping itu, penelusuran terhadap teks naskah-naskah Sunda Kuna masa pra-Islam telah memberikan informasi lengkap terdapat keberadaan konsep pemerintahan Sunda masa lampau. Tujuan penelitian ini adalah menemukenali prinsip-prinsip pemerintahan tradisional dalam kerangka memahami kepemimpinan orang Sunda. Kampung Naga dalam kesehariannya dewasa ini lebih kental dan menonjol unsur keagamaannya, yaitu agama Islam. Akibatnya adalah konsep tritangtu nyaris hilang dan tak dikenal lagi. Hasil penelusuran pada tatanan pemerintahan dan 'artefak' fisik Kampung Naga ciri pemerintahan tradisional masih terlihat dalam bentuk lain.
\end{abstract}

Kata kunci: Tritangtu, rama, prabu, resi, leuweung (hutan), Kampung Naga.

\section{Abstract}

Tritangtu di Bumi (three-power on Earth)is a traditional Sundanese ruling system that divides power into three roles: Rama (God), prabu (human being), and resi (mother nature). The system can be traced to many kampung adat (villages that preserved traditional customs/adat), one of which is Kampung Naga.

The author conducted a descriptive method in describing daily life of Kampung Naga's society. Ancient Sundanese manuscripts are also studied in tracing concepts of pre-Islamic Sundanese ruling system.

The purpose of the research is to rediscover traditional Sundanese ruling principles in order to understand leadership in Sundanese's point of view.

Islamic practices performed by Kampung Naga/s society today have made concept of tritangtu vanished, but the artifacts are still recognized.

Keywords: Tritangtu, god, human, nature, forest, Naga Village.

\section{A. PENDAHULUAN}

Keberadaan Kampung Adat, khususnya di Jawa Barat, yang memiliki kekhasan dan kemandirian sikap sangat menarik untuk dikaji. Kita tidak bisa menutup mata akan kemampuan mereka mempertahankan diri di tempat yang jauh dari keramaian, bahkan seringkali 
mencengangkan orang lain dan dianggap memiliki nilai budaya yang tinggi. Misalnya makna yang dapat diambil dari 'pikukuh' (adat, aturan) orang Kanekes (Baduy) yang berbunyi:

Najan nepi ka mupak alam dunya, adat mah teu wasa dirobah, lojor teu meunang dipotong, pandak (pondok) teu meunang disambung, sajadina bae (Walau hingga alam dunia hancur, adat tak kuasa diubah, panjang tak boleh dipotong, pendek pun tak boleh di sambung).

Ungkapan ini memberi petunjuk akan pola pikir positif yang merupakan dasar normatif bagi kaedah dan hukum sebagai pedoman hidup warga masyarakat (Garna, 1994/1994:4).

Namun hal terpenting bagi kita dalam kaitannya dengan keberadaan kampung adat adalah menjadikan kampung adat sebagai "prototipe" masyarakat Sunda. Artinya keberadaan kampung adat cukup representatif guna mewakili tata kehidupan orang Sunda masa silam. Dalam pengertian, -walau tidak secara utuh- dapat memberikan pemahaman atas sejumlah persoalan mengenai adat-istiadat, kepercayaan (religi), pemerintahan, seni budaya, sistem pertanian dan berbagai aspek kehidupan orang Sunda.

Kesalahan yang tidak disengaja ketika sosok orang Sunda mencari jati dirinya adalah mengabaikan peranan masyarakat adat. Ketika seorang budayawan berbicara tentang budaya Sunda, seringkali menafikan atau mengabaikan tatanan kehidupan masyarakat yang berada di kampung adat. Padahal tidak mustahil pada diri mereka sebenarnya letak semua jawaban atas pertanyaan yang dicari orang Sunda masa kini. Berdasarkan pendataan Balai Pelestarian Sejarah dan Nilai Tradisional terdapat beberapa kampung adat yang memiliki pendukung cukup besar, salah satunya adalah Kampung Naga di Tasikmalaya. Secara administratif kampung ini masuk wilayah Kecamatan Salawu Desa Neglasari dan berada di tepi Sungai Ciwulan.

Penelaahan atas buku atau laporan penelitian mengenai Kampung Naga telah banyak dilakukan, terutama dari sisi kultur dan sosial-budaya. Misalnya, Murniatmo G. et al. (1987) mengenai Kehidupan Sosial Budaya Orang Naga, Salawu Tasikmalaya Jawa Barat; Oyon Sofyan Umsari, dkk. (1985/1986) mengenai Bahasa Sunda Kampung Naga; A. Suhandi Sumamihardja mengenai Kesenian, Arsitektur Rumah dan Upacara Adat Kampung Naga Jawa Barat; di bidang lingkungan penelitian tercatat dilakukan oleh Sony Suhandono (1996) tentang Etnobotani Orang se Naga yang mengemukakan tumbuhtumbuhan obat. Penelitian-penelitian lain pun yang berkaitan dengan Kampung Naga masih banyak dan (sebaiknya) dijadikan acuan dalam meneliti berbagai persoalan di Kampung Naga.

Persoalan lain yang tak kalah menarik adalah sistem pemerintahannya, yakni pikukuh tilu atau hukum tangtu yang merupakan sistem pemerintahan tradisional ala Sunda. Konsep pemerintahan tersebut baik tersirat dalam sisa-sisa budaya maupun tersurat dalam naskah-naskah Sunda menjadi pijakan awal dalam 
penelusuran sistem (organisasi) pemerintahan masa lampau. Jadi, masalah yang akan dikaji adalah apakah pikukuh tilu (Tritangtu di Bumi) yang merupakan konsep pemerintahan Sunda masa lalu - masih digunakan oleh penduduk Kampung Naga? Atas dasar tersebut maka tujuan penelitian adalah menemukenali prinsip-prinsip pemerintahan dan kepemimpinan orang Sunda.

Selanjutnya, guna mencapai tujuan yang diharapkan, penelitian menempuh pendekatan kualitatif (Maryaeni,2005:3) yaitu memahami fakta yang ada di balik kenyataan yang dapat diamati atau diindra secara langsung. Dengan bahasa lain penelitian kualitatif adalah medan penemuan pemahaman yang merupakan kegiatan yang tersusun atas sejumlah wawasan, disiplin, maupun wawasan filosofis sejalan dengan kompleksitas pokok permasalahan yang digarap. Sementara itu Surakhmad, (1982:139) mengemukakan metode deskriptif-kualitatif adalah suatu cara yang digunakan untuk menyelidiki dan memecahkan masalah yang tidak terbatas pada pengumpulan dan penyusunan data saja, tetapi meliputi analisis dan interpretasi data sampai kepada kesimpulan yang didasarkan atas penelitian. Atas uraian tersebut metode yang digunakan dalam penelitian ini adalah metode kualitatif.

\section{B. HASIL DAN BAHASAN}

\section{Triumvirate (Kekuasaan Tiga Serangkai)}

Konsep harmoni dengan alam sering menunjukkan pada keselarasan antara manusia dengan lingkungannya.
Istilah keseimbangan sering pula digunakan untuk menghubungkan antara kebutuhan jasmani dan rohani. Dalam lingkup lebih luas lagi keselarasan dan keseimbangan harus mencakup keterjalinan dunia mikrokosmos dan makrokosmos yang pada masyarakat adat disebut dunya badag dan dunya lembut. Sementara itu konsep hukum papasangan, "hukum dualisme" sering dinisbatkan pada "hukum kepastian" yang mau tidak mau harus demikian tanpa ada pilihan lagi (pasti). Misalnya, setiap makhluk di dunia ini selalu berpasangan (hukum papasangan): siang - malam; matahari - bulan; perempuan - laki-laki, positif negatif, kanan - kiri, daratan - lautan ; hidup- mati ; dan sebagainya. Kalaulah salah satunya tidak ada atau terganggu mekanismenya maka itulah yang dinamakan bencana, kecelakaan atau sebutan lain yang semakna dengan itu.

Adalah sebuah fakta lain, dalam khasanah budaya Sunda, yang sering tidak disadari oleh orang Sunda sendiri mengenai ucapan-ucapan yang membatasi diri dalam hitungan ketiga. Ketika seseorang akan melakukan sesuatu pekerjaan yang membutuhkan kesiapan pihak lain, tanpa disadari ia menghitung sebanyak tiga kali hitungan. Misalnya seseorang yang akan memotret, ia akan menghitung tiga kali hitungan untuk mengingatkan obyek dalam berpenampilan. Di lain pihak ungkapan atau peribasa Sunda yang berbunyi Nista madya utama memperkuat dugaan adanya makna tertentu dalam tatanan "kepercayaan" orang Sunda.

Peribahasa Nista maja utama mempunyai latar belakang norma hukum sosial yang ditimpakan kepada individu maupun kelompok yang 
mempunyai kesalahan atau kelalaian. "Hukuman" yang dijatuhkan merupakan sikap kejengkelan kepada individu atau kelompok tersebut yang sudah tidak dapat lagi diperbaiki untuk mengubah (memperbaiki) perilakunya. Kamus Basa Sunda yang ditulis R. Satjadibrata menjelaskan arti Nista madya utama:

dilisankeun ka jelema nu geus tilu kali ngalampahkeun kajahatan teu meunang dibere ampun (Nista madya utama: diucapkan kepada orang yang telah tiga kali melakukan kesalahan/kejahatan yang tidak boleh diberi ampun lagi).

Secara harfiah triumvirate berarti tritunggal, tiga serangkai; namun istilah ini sering digunakan dalam bidang pemerintahan yang berarti kekuasaan dipegang oleh tiga orang sebagai kesatuan.

Abad 16 - 17 dunia Eropa disibukkan dengan kekuasaan raja yang sewenang-wenang dan bersifat totaliter. Sistem totaliter ini mengakibatkan raja memerintah tanpa batas dan memerintah sekehendak hatinya tanpa mengindahkan hak-hak atau kemerdekaan warga negara. Hal tersebut mengundang reaksi dari warga negaranya, terutama kalangan cendekiawannya. Adalah Montesquieu (1689--1755), mengemukakan pandangannya mengenai pemisahan kekuasaan yang kemudian terkenal dengan sebutan Trias Politika. Ajaran ini dimuat dalam bukunya, De l'esprit des lois (Jiwa Perundang-undangan) yang diterbitkan pada tahun 1748 (ENI 16,199:440).
Trias politika adalah teori ketatanegaraan atau Hukum Tata Negara yang membagi dan memisahkan kekuasaan negara menjadi tiga, yaitu: (1) kekuasaan legislatif (pembuat undang-undang);

kekuasaan eksekutif (pelaksana atau penyelenggara undang-undang); (3) kekuasaan yudikatif (pengadilan, mengadili para pelanggar undangundang).

Sesungguhnya apa yang dikemukakan Montesqieu dengan Trias Politikanya, sebagaimana diungkap di atas, bukan hal (informasi) baru bagi peneliti sejarah. Kalaulah kita menarik diri, melihat jauh ke belakang, ketika masa kerajaan di Nusantara masih berjaya; kita akan mengakui kepiawian leluhur negara ini dalam mengatur pemerintahannya (baca: kerajaannya). Hal itu dapat kita pelajari pada "sisasisa" artefak sistem pemerintahan masa lalu yang ada di kampung-kampung adat, terutama dalam lembaga-lembaga adat di Nusantara. Misalnya, Lembaga Adat di Minangkabau (Sumatra Barat): Tigo Tungku Sajarangan terdiri atas Ninik Mamak, Cerdik Pandai dan Alim Ulama. Masyarakat Adat Batak (Sumatra Utara) mengenal Dalihan $\mathrm{Na}$ Tolu terdiri atas: Hula-hula, Boru dan Dongan Tubu. Masyarakat adat di kaki Gunung Rinjani di Pulau Lombok dengan istilah Watu Tolu. menurut keterangan lisan Saleh Danasasmita (alm), konon pada tahun 1677 Kesultanan Cirebon pun dikuasai oleh Trio Penguasa, yaitu: Sultan Sepuh, Sultan Anom dan Panembahan Cirebon (Djatisunda,2002:5) 


\section{Berita di Masa Lalu: Informasi Naskah Kuno Sunda}

Sejumlah naskah berbahasa Sunda Buhun mengandung rucita (konsep) kepemimpinan yang dapat dijadikan rujukan dalam upaya memahami citra kepemimpinan tradisional Sunda berdasarkan naskah dan prasasti. Di antara naskah itu yang terpenting adalah Sanghyang Siksa Kanda ng Karesian (SSKK) dari tahun 1518 (Aca,1972) dan oleh Suhamir (1961) disebut sebagai "ensiklopedi Sunda". Naskah lainnya adalah Carita Parahyangan (CP) dari tahun 1580 (Aca,1967), berupa sebuah "iktisar sejarah" Tatar Sunda sejak masa kerajaan Galuh dan Sunda hingga keruntuhan kerajaan Pajajaran (669 -1579), dan Sewakadarma (SD) yang tanpa tahun (Danasasmita dkk,1987) namun diperkirakan berasal dari masa yang hampir sama atau bahkan lebih tua (Ayatrohaedi, 2001).

\section{SSKK}

Ini beberapa kutipan dari naskah

Nihan sinangguh dasaprebakti ngaranya, anak bakti di bapa, ewe bakti di salaki, hulun bakti di pacandaan, sisya bakti di guru, wang tani bakti di wado, wado bakti di mantri, mantri bakti di nu nangganan, nu nangganan bakti di mangkubumi, mangkubumi bakti di ratu, ratu bakti di dewata, dewata bakti di hyang ya ta sinangguh dasa-prebakti ngaranna.

Artinya:

Inilah yang disebut Dasaprebakti, sepuluh kebaktian,: Anak berbakti kepada ayah, istri berbakti kepada suami, hamba berbakti kepada majikan, siswa berbakti kepada guru, petani berbakti kepada wado, wado berbakti kepada nu nangganan, nu nangganan berbakti kepada mangkubumi, mangkubumi berbakti kepada raja, raja berbakti kepada dewata, dewata berbakti kepaya hyang. Ya itulah yang disebut Dasaprebakti namanya.

ini ujar sang sadu, basana mahayu drebyana ini Tritangtu di Bumi bayu kita pinaka prebu, sabda kita pinaka rama, hedap kita pinaka resi, ya Tritangtu di Bumi ya kangken pineguh ning bwana ngaranna

Artinya: inilah nasihat Sang Budiman
ketika pribadinya. Inilah tiga ketentuan di dunia: kesentosaan kita bagaikan raja, ucap kita ibarat tetua, budi kita ibarat resi. Itulah Tritangtu di Bumi yang disebut (sebagai peneguh dunia).

Naskah SSKK merupakan salah satu sumber penting dalam upaya memahami kehidupan masyarakat Sunda masa silam, terutama pada masa sebelum masuknya pengaruh Islam. Dilengkapi berbagai lembaran yang terdapat dalam naskah lain $(\mathrm{CP}, \mathrm{SD}$, Carita Ratu Pakuan, Galunggung, Buhangga manik, Waruga Jagat) dapat diperoleh gambaran hal-hal yang berkenaan dengan kehidupan masyarakat Sunda sebelum Islam itu. Hal-hal yang agak jelas terdapat dalam naskah-naskah itu antara lain yang 
berkenaan dengan "birokrasi" dan pembagian kekuasaan, pelapisan masyarakat, kesehatan dan lingkungan dan hubungan yang terjadi dalam tata masyarakat pada masa itu.

Rucita Dasaprebakti dalam SSKK menggambarkan bahwa pejabat yang paling dekat hubungannya di bawah raja adalah mangkubumi, perdana mentri. Ia bertanggung jawab atas segala sesuatu yang terjadi atau dilakukan oleh bawahannya, nu nangganan, lalu berturut-turut ke bawah ada mantri dan wado. Jabatan nu nangganan juga tercatat dalam naskah Carita Ratu Pakuan: /10b/ (......) tan liya girang nangganan $n u$ /l1a/ nangganan para putri nu geulis (....) "Tidak lain (daripada) girang nangganan yang menangani (mengasuh?) para putri yang jelita" (Atja,1970:35--6). Jadi, nu nangganan adalah pejabat yang cukup memperoleh kepercayaan dari raja.

Dengan demikian, barangkali struktur kerajaan Sunda dapat dibinaulang sebagai berikut: Di tingkat pemerintah pusat, kekuasaan tertinggi berada di tangan raja. Dalam pelaksanaan tugasnya sehari-hari, raja dibantu oleh mangkubumi yang membawahi beberapa orang $n u$ nangganan. Di samping itu, ada putra makuta yang akan menggantikan kedudukan raja jika raja meninggal atau mengundurkan diri. Untuk mengelola wilayah yang sangat luas itu, raja dibantu oleh beberapa orang raja bawahan atau raja daerah. Rajaraja itu melaksanakan tugas mereka sehari-hari bertindak sebagai raja yang merdeka, namun mereka tetap mengakui raja Sunda sebagai jungjunan mereka. Dalam hal raja tidak mempunyai anak laki-laki yang berhak menggantikannya sebagai raja, tahta dapat beralih kepada menantunya. Jika putra makuta masih terlalu muda untuk memegang tampuk pemerintahan, mangkubumi dapat bertindak sebagai pejabat sementara raja. Dalam pada itu, untuk masalah perniagaan, di bandarbandar kerajaan raja diwakili oleh syahbandar yang bertindak untuk dan atas nama raja Sunda di bandar yang dikuasakan kepada mereka.

Struktur kerajaan itulah yang dianggap paling sesuai untuk kerajaan Sunda. Berbagai carita Pantun juga pada umumnya mengisahkan seorang anak raja Pajajaran yang mengembara, dan dalam pengembaraannya ia menaklukan berbagai raja kecil. Setelah raja-raja itu takluk, mereka diangkat kembali sebagai penguasa di daerahnya dengan syarat harus mengakui kekuasaan tertinggi yang berada di Pakuan Pajajaran.

Seperti ditegaskan dalam SSKK, terdapat "tria politika" Sunda di masa lampau. Pedoman itu disebut tritangtu (di bumi) yang pelaksanaannya muncul dalam wujud triwarga di lamba. Pedoman itu mengatur dan menata fungsi, kedudukan, dan peran yang melekat pada unsur-unsur tritangtu itu. Tujuannya adalah untuk menyentosakan pribadi (seseorang). Ia harus sentosa bagaikan raja, ucapannya harus dapat dipegang bagaikan petuah para tetua, sedangkan budinya haruslah bagaikan budi seorang resi. Tritangtu itulah yang disebut sebagai peneguh dunia.

ini triwarga di lamba wisnu kangken prabu, brahma kangken rama, isora kangken resi, nya mana tritangtu pineguh ning 
bwana, triwarga hurip ning jagat ya sinangguh tritangtu di nu reya ngaranya

Artinya:

Inilah triwarga di lamba, tiga golongan dalam kehidupan, Wisnu ibarat raja, Brahma ibarat tetua (=rama). Isora (Iswara) ibarat resi, karena itulah tritangtu menjadi peneguh dunia, triwarga menjadi kehidupan di dunia. Ya disebut sebagai tritangtu pada orang banyak.

Naskah Amanat Galunggung atau koropak 632 menjelaskan tentang kedudukan Tritangtu di Bumi yaitu rama - resi - ratu, ketiga tiganya mempunyai tugas yang berbeda tetapi tidak dapat dipisah-pisahkan. Tidak ada diantara mereka yang berkedudukan lebih tinggi dari yang lainnya. Tugasnya setara dan sama-sama mulia. Ketiga pemimpin tersebut harus bersama-sama menegakkan kebajikan dan kemuliaan melalui ucapan perbuatan. Dunia kemakmuran tanggungjawab sang rama, dunia kesejahteraan hidup tanggungjawab sang resi, dunia pemerintahan tanggungjawab sang prabu/ratu . Jagat palangka di sang prabu, jagat daranan di sang rama, jagat kreta di sang resi.

Tritangtu di Bumi merupakan pembagian peran di dalam tatanan sosial dan negara, yang dalam hal ini masing-masing bagian mempunyai wilayah teritorial sendiri. Bila kita bandingkan tugas masing-masing unsur, maka -seperti Tritangtu yang lain- Tritangtu di Bumi juga merupakan refleksi dan representasi 3 unsur yaitu Tuhan, Alam, dan Manusia.
Rama: Representasi dari unsur Tuhan yang dimanifestasikan dalam tugas Rama yaitu bidang spiritual, yakni seorang Rama ini adalah manusia yang sudah meninggalkan kepentingan yang bersifat duniawi dan lahiriah, sehingga bisa menjaga rasa asih yang tinggi dan bijaksana.

Resi: Representasi dari unsur alam yang merupakan penyedia bagi kepentingan kehidupan, maka para Resi merupakan ahli-ahli atau guru-guru dalam berbagai bidang di antaranya: pendidikan, pertanian, militer, seni, perdagangan, kesehatan dan lain sebagainya Misinya adalah asah.

Ratu (Prabu): sebagai reprensentasi unsur manusia yang bertugas untuk mengasuh seluruh kegiatan dan kekayaan negara karena misinya asuh maka di dalam tatanan Sunda para pemimpin pemerintahan ini disebut pamong atau pangereh dan bukan pemerintah.

\section{Kampung Adat Pewaris Tritangtu}

Berbicara tentang kampung adat (Sunda) artinya kita berupaya memahami berbagai aspek kehidupan manusia Sunda. Sebuah kampung adat akan mempunyai ciri atau kriteria yang menunjukkan pada eksistensinya sebagai pewaris atau penjaga budaya tradisi wrisn leluhurnya. Dalam hal ini Sucipto (2005), mengemukakan masing-masing tiga kriteria mengenai eksistensi sebuah kampung adat dan masyarakat adat. Sebuah kampung adat dikatakan kampung adat apabila memenuhi tiga unsur berikut, yaitu (1) menempati wilayah yang tetap dalam waktu relatif lama (keterikatan terhadap tanah yang diwarisi secara turun temurun sangat kuat); (2) memiliki lembaga adat: ketua adat 
(kuncen, puun, olot, abah), pembantu ketua adat (bareusan kolot, kokolot, sesepuh, lawang); dan (3) kampung adat adalah permukiman masyarakat adat yang masih kuat mempertahankan tradisi warisan leluhur; yang paling menonjol, ditandai dengan samanya bentuk dan bahan bangunan rumah. Sedangkan masyarakat adat mempunyai kriteria (1) menempati wilayah yang tetap dalam waktu relatif lama (keterikatan terhadap tanah yang diwarisi secara turun temurun sangat kuat); (2) masih kuat mempertahankan tradisi warisan leluhur; (3) memiliki lembaga adat: ketua adat (kuncen, puun, olot, abah), pembantu ketua adat (bareusan kolot, kokolot, sesepuh, lawang)

Kuatnya mempertahankan tradisi leluhur sebagai kriteria utama dalam menentukan sebuah perkampungan adat membawa implikasi adanya pandangan bahwa sebuah kampung adat merupakan prototipe masyarakat Sunda masa lalu. Kampung adat berfungsi sebagai "foto" atau "potret" yang menginformasikan dunia lampau pada masa sekarang. Dengan demikian mudah dimengerti apabila konsep tritangtu atau pikukuh hukum tilu masih bertahan dewasa ini, terutama di kampung adat Kanekes (Baduy) di Banten dengan sebutan Teulu Tangtu, dan kampung adat yang tergabung dalam sebutan Pancer Pangawinan. Djatisunda (2002) dalam makalahnya secara ringkas menjelaskan bahwa ketiga puun di Kampung Tangtu (Kampung Baduy Dalam) seperti Cikeusik (Tangtu Padaageung), Cikartawana (Tangtu Kadukujang) dan Cibeo (Tangtu Parahiyangan), masing-masing menyandang fungsi sebagai Puun Rama, Puun Pandita, dan Puun Ponggawa (pengganti Prebu). Kata Puun berarti pohon, pokok, pangkal. Sistem tiga puun dengan fungsi demikian, masyarakat Urang Rawayan (Baduy) menyebutnya Tangtu Teulu (= Tritangtu).

Pada hakikatnya ketiga puun tersebut memiliki kedudukan yang sama, namun jika dilihat dari derajatnya, Puun Tangtu Cikeusik dianggap sebagai yang tertua diantara dua puun yang lain, meskipun usia pejabat puun Cikeusik pada periode tertentu lebih muda dari puun Cikartawana dan Cibeo. Hal tersebut sangat beralasan, sebab Puun Cikeusik sebagai Puun Rama (= ayah) adalah tokoh "Pendiri kampung" yang kedudukannya berlanjut secara turun temurun. Tugasnya adalah "daranan" yang berarti membawa atau mengendalikan. Dalam naskah Amanat Galunggung (koropak 632) disebutkan bahwa "Sang Rama enak amangan". Kata lamang/ atau lamwang/ sama dengan kata bahasa Jawa "among" yang artinya mengemong atau mengasuh. Dalam hal ini sangat jelas bahwa Tangtu Cikeusik menyandang fungsi terselubung sebagai pembimbing dari dua Tangtu lainnya di samping Tangtunya sendiri. Selanjutnya, oleh karena ketiga kampung Tangtu tadi masing-masing dipimpin oleh seorang Puun, maka ketiga kampung Tangtu itu oleh warga Baduy Panamping dan Dangka lajim disebut Kapuunan atau Padaleuman Puun.

Sistem kepemimpinan Tangtu yang berjumlah Teulu (tiga buah) sebagaimana dikemukakan, dalam lembaga adat Sunda Wiwitan Urang 
Rawayan terdapat pula organ kelembagaan yang juga berjumlah tiga buah seperti dalam struktur kemasyarakatan secara adat yang diistilahkan Suhun Teuleu terdiri atas Suhun Tangtu, Suhun Panamping dan Suhun Dangka, lazim pula disebut Kajeroan (Baduy Dalam), Kaluaran (Baduy Luar) dan Dangka. Selain itu dalam tahap pandangan spiritual "kamandalaan" ada yang disebut $A m b u$ Teulu (Buana Teulu), yaitu: (1) Ambu Luhur (Buana Nyungcung) yaitu dunia atas yang sangat luas tanpa batas; (2) Ambu Tengah (Buana Tengah) atau Buana Panca Tengah yaitu dunia tengah tempat manusia hidup dalam pengembaraannya; (3) Ambu Handap (Buana Handap) lajim disebut Buana Larang yaitu dunia bawah yang sangat luas tak terbatas. Buana Larang ini menurut keyakinan ajaran Sunda Wiwitan, merupakan tempat menunggunya para arwah orang yang meninggal dunia sebelum tiba saatnya naik ke Bumi Suci Alam Padang (Ambu Luhur) ke pangkuan Sanghyang Sunan Ambu.

Ketiga Ambu (buana) itu disimbolkan pula dalam pendirian bangunan rumah panggung, yang sampai sekarang mesti mengandung ketiga unsur tersebut yang diwujudkan dalam bentuk bagian atap rumah (luhur), bagian tengah rumah (tengah) dan bagian kolong rumah (handap). Demikian pula dalam konsep pendirian kampung, pada awalnya berpatokan kepada angka tiga, yaitu tiga kampung inti (Tangtu) dan tigapuluh kampung Kaluaran dan Dangka, yang lajim disebut Nusa teulu puluh teulu.

Selanjutnya, masih menurut Anis Jatisunda masyarakat adat Pancer Pangawinan tersebar di tiga daerah wilayah tiga kabupaten di Jawa Barat dan Banten. Diantaranya di Kampung Urug di Desa Kiarapandak Kecamatan Cigudeg Kabupaten Bogor (Jawa Barat); Di Kampung Citorek Kecamatan Bayah Kabupaten Lebak (Banten) dan Kampung Ciptagelar Kecamatan Cisolok Palabuhanratu Kabupaten Sukabumi (Jawa Barat).

Kata Pangawinan, menurut berita Pantun Bogor berawal dari nama suatu kelompok barisan pengamanan Pakuan Pajajaran yang disebut "Bareusan Pangawinan". Kata "Pancer" berarti patokan, pokok, pangkal; mungkin sebagai pengganti kata "bareusan". Alasan ini bisa dimengerti, sebab dengan sirnanya Pakuan Pajajaran digempur Banten, Demak, dan Cirebon, Bareusan Pangawinan pun turut bubar. Para keturunannya yang kini masih ada, menganggap bareusan Pangawinan ini sebagai cikal bakal mereka, dengan sebutan Pancer tadi, Pancer Pangawinan. Demi menjaga segi keamanan, sebutan Pancer Pangawinan mungkin sebagai pengganti dari sebutan Pancer Pajajaran, yang jika secara terbuka dikemukakan demikian dikhawatirkan akan jadi incaran warga Banten yang menjadi musuh leluhur mereka pada masa silam.

Beralih pada sistem

kepemimpinan Tritangtu, strata kemasyarakatan tradisional Pancer Pangawinan pun mempunyai kesamaan meski dengan sedikit perbedaan. Terdapatnya tiga kampung inti seperti dikemukakan di atas, mengindikasikan adanya jalinan keadaan yang sama. Hal ini ditandai dengan terdapatnya suatu lembaga bentukan baru yang disebut Kasatuan Banten Kidul. Dibentuknya lembaga ini hanya untuk menyeimbangkan dengan struktur 
organisasi kemasyarakatan jaman kini. Sedangkan secara hakiki dibaliknya secara terselubung masih tetap berpegang kepada sistem kemasyarakatan secara adat. Kampungkampung inti tersebut menggunakan istilah Kokolotan yang dalam bahasa Sunda halusnya disebut Kasepuhan.

Istilah Kokolotan sampai kini masih digunakan bagi Kampung Citorek dan Kampung Urug yang ketua adatnya di Citorek disebut Karolot disingkat Oyok dan di Kampung Urug disebut Kolot disingkat Olot. Sedangkan di Kampung Ciptagelar sudah menggunakan bahasa Sunda halus dengan istilah Kasepuhan dengan sebutan ketua adatnya Abah.

Melihat latar belakang sejarah perkembangannya, Ketua adat di Kampung Citorek, sampai Aki Kaderin masih dijuluki Ama berupa kata singkatan dari Rama dan di Kampung Cikaret jaman Ki Buyut Kayon sampai Ki Jasiun masih disebut Perbu. Hanya ketua adat Kampung Urug yang sepertinya kehilangan istilah kunonya. Namun dengan ditemukannya istilah di kedua kampung adat inti Citorek dan Cikaret, sudah bisa disimpulkan bahwa Kampung Urug dipastikan berupa kampung tempatnya Resi. Dengan demikian jika diselaraskan dengan sistem kepemimpinan tradisional Sunda lama Tritangtu di Buana atau Tangtu Teulu, maka ketiga kampung masyarakat adat Pancer Pangawinan itu terdiri atas Citorek sebagai tangtu Rama, Cikaret atau sekarang Kampung Ciptagelar sebagai Tangtu Prebu dan Kampung Urug sebagai Tangtu Resi.

\section{Kampung Naga: Sistem Pemerintahan}

Berbeda dengan kondisi Urang Rawayan - memakai istilah Anis Jatisunda untuk mengganti nama Baduy- di Banten dan Pancer Pangawinan di Sukabumi, Bogor dan Banten yang masih konsisten atau sekurang-kurangnya masih dapat dilacak jejak pemakaian Tritangtu, maka di Kampung Naga bukanlah hal yang mudah. Seorang informan malah kebingungan manakala ditanyakan mengenai istilah Tritangtu di Bumi, pikukuh tilu atau hukum tilu. Seolaholah baru mendengarnya dan asing ditelinga. Oleh karena itulah guna melacak "keberadaan" Tritangtu di Kampung Naga, mau tidak mau kita harus menganalisis berbagai aspek kehidupannya; salah satunya adalah menganalisis sistem pemerintahannya.

Secara umum kepemimpinan di kampung-kampung adat terdiri atas dua kepemimpinan, yaitu; kepemimpinan formal dan Non formal. Kepemimpinan formal adalah kepemimpinan yang termasuk ke dalam struktur organisasi desa, yaitu RK dan RT. RT dan RK merupakan ujung tombak yang berfungsi sebagai penghubung atau perantara dari aparat pemerintah terhadap masyarakat. Hampir setiap program ataupun kebijakan pemerintah yang akan diterapkan di Kampung Naga, selalu terlebih dahulu dimusyawarahkan dengan pimpinan adat. Dalam hal ini peranan RT dan RK menjadi sangat penting karena mereka yang secara langsung berhadapan dengan pimpinan adat.

Kepemimpinan non-formal atau kepemimpinan adat adalah kepemimpinan yang khusus mengurusi 
kehidupan adat istiadat yang berlaku dan harus dipertahankan dan dilaksanakan oleh segenap anggota masyarakat Kampung Naga. Pada tatanan inilah sebenarnya konsep pemerintahan Sunda (Tritangtu) dapat dicari atau ditelusuri,mengingat pembentukan pemerintahan formal melalui desa atau kelurahan merupakan perpanjangan tangan dari pemerintahan pusat Republik Indonesia.

Seorang informan menjelaskan mengenai struktur lembaga adat (organisasi) Kampung Naga adalah sebagai berikut:

Kepemimpinan adat terdiri atas 3 unsur, yaitu Kuncen, Lebe dan Punduh. Kuncen atau pemangku adat adalah pemimpin dan pelaksana pengendali dan memiliki kewenangan untuk menyelesaikan masalah yang dihadapi masyarakatnya, baik yang berhubungan dengan adat maupun dengan tugastugas dari pemerintah setempat, serta mempunyai kekuasaan dan otoritas yang juga dibatasi dan dikontrol oleh adat yang berlaku. Seorang kuncen dipandang dan diakui oleh masyarakat sebagai orang yang paling mengetahui tentang adat-istiadat. Ia adalah pewaris utama dan penguasa tinggi adat (Maria,1995:23). Oleh karena itu, kuncen secara langsung maupun tidak langsung bertanggungjawab atas kelangsungan adat dan hidup keturunannya. Kuncen juga menjadi panutan bagi setiap warga Kampung Naga dalam melaksanakan tindakan dan perbuatan yang sesuai dengan ketentuan adat yang berlaku .

Dalam menjalankan tugasnya Kuncen dibantu oleh Lebe dan Punduh. Lebe bertugas sebagai pelaksana teknis upacara perkawinan dan kematian dan membantu tugas kuncen apabila ber- halangan. Sedangkan Punduh mempunyai tugas utama menjadi penghubung dengan sistem administrasi pemerintah desa dan sering juga mewakili penyambutan tamu.

Jabatan kuncen berlaku secara turun-temurun dan hanya boleh dijabat oleh laki-laki. Lamanya jabatan juga tidak dapat ditentukan secara pasti, melainkan berdasarkan pada kemampuan menjalankan tugasnya, atau apabila Kuncen meninggal, maka ia dapat digantikan oleh anak lakilakinya yang sudah dewasa atau anak laki-laki dari saudara lakilaki/perempuannya. Kedewasaan seseorang ditentukan oleh batas umur 35 tahun dan sudah berkeluarga. Kebiasaan ini sudah merupakan ketentuan sejak nenek moyang mereka, sehingga segala ketentuan yang telah ditetapkan senantiasa dipatuhi. Seseorang dapat saja menjadi kuncen walaupun belum mencapai usia 35 tahun, asalkan ia sudah berkeluarga dan memiliki pengetahuan mengenai cara memimpin dan melaksanakan upacaraupacara adat, sebab pengetahuan tersebut telah diturunkan jauh sebelumnya, sebelum ia menjadi kuncen. Artinya segala sesuatu yang menyangkut masalah kepemimpinan adat berikut memimpin upacara adat tersebut telah diperolehnya sebelum atau sesudah menduduki jabatan kuncen, walaupun belum mencapai usia 35 tahun. Namun mengenai asal-usul adat seNaga arti dan maksud istilah Naga hanya akan diturunkan kepada seorang kuncen apabila ia sudah mencapai umur 35 tahun.

Adanya tiga komponen pemerintahan di Kampung Naga (Kuncen, Lebe, dan Punduh) sedikit 
banyaknya memberi gambaran adanya konsep Tritangtu masih digunakan. Walaupun pada kenyataannya mereka tidak mengetahui atau tidak mengakui apa yang mereka perbuat itu merupakan refleksi dari Tritangtu. Oleh karena - jika kita melihat tugas dan fungsinya ketiga komponen pemerintahan Kampung Naga itu sangat merujuk pada pembagian wewenang. Kuncen mengurusi bidang adat, Lebe mengurusi bidang keagamaan, dan Punduh mengurusi bidang pemerintahan, bukankah hal ini merupakan konsep Rama, Prabu dan Resi? Kuncen diidentikan dengan Rama, Lebe dianalogikan dengan Resi dan Punduh disejajarkan dengan konsep Prebu dalam Tritangtu. Memang dalam praktiknya, ketiga jabatan itu sepenuhnya berada di tangan Kuncen; artinya Punduh dan Lebe tunduk pada Kuncen, sementara kuncen itu sendiri tunduk pada adatistiadat yang berlaku di Kampung Naga tersebut.

Peran Kuncen sebagai kokolot akan langsung memimpin warganya, demikian juga terhadap pemerintah, mereka akan taat dan segala tugas dilaksanakan dengan sebaik-baiknya. Ketaatan dan kesungguhan mengabdi kepada orang yang memerlukan, termasuk kepada pemerintah, itu dilandasi falsafah hidupnya. Mereka, masyarakat Naga, mengatur pengabdian pada negara dan agama dilandasi tiga hal, yaitu: (1) pamunut gancang caosan (Permintaan segera penuhi); (2) parentah gancang lakonan (Perintah segera laksanakan); dan (3) panyaur gancang temonan (Panggilan (undangan) segera datangi) (Ahman Sya,2008:33)

\section{5. "Fisik Tritangtu ": Pola Perkampungan dan Rumah}

Pengamatan atas pola perkampungan Kampung Naga menunjukkan adanya penyesuaian dengan keadaan tanah (fisiologi tanah). Perkampungannya disesuaikan dengan letak ketinggian tanahnya yang tidak sama. Akibatnya adalah letak rumah perkampungan disusun bertingkattingkat dari bagian tanah yang paling rendah hingga bagian tanah yang paling tinggi. Posisi seperti ini dalam pandangan kosmologi bukanlah tidak bermakna. Bukankah posisi tertinggi merupakan hirarki "tersuci" atau batas kemampuan manusia didalam merefleksikan kesempurnaan? Bukankah komplek pemakaman Imogiri di Jawa Tengah berada di sebuah pegunungan yang tinggi? Demikian pula Gunung Himalaya dalam kepercayaan masyarakat setempat merupakan tempat para dewa?

Secara kasat mata posisi perkampungan Kampung Naga dapat digambarkan sebagai berikut: seluruh rumah dan bangunan-bangunan lain atapnya memanjang dari arah barat ke timur, pintu masuk terletak di sebelah Timur menghadap Sungai Ciwulan. Di bagian Tengah adalah lapangan dan beberapa buah rumah penduduk serta mesjid. Sejajar dengan mesjid, di sebelah Barat pada bagian yang lebih tinggi letaknya terdapat Bumi Ageung, tempat menyimpan barang-barang pusaka. Sedangkan sejajar dengan bangunan Bumi Ageung arah sebelah Selatan terletak rumah kuncen dan beberapa rumah penduduk lainnya. Di sekeliling tanah lapang tersebut mengelompok ke arah Selatan terletak rumah-rumah penduduk dan rumah 
Kepala Rukun Kampung atau RK. Selain itu terdapat lumbung padi yang disebut leuit tempat menyimpan padi penduduk. Dalam cakupan lebih luas, pola perkampungan Kampung Naga memosisikan diri ke dalam tiga wilayah (ruang), yaitu Leuweung Larangan (terletak di seberang sungai Ciwulan sebelah timur perkampungan), perkampungan (posisi tengah), dan leuweung karamat (di sebelah barat, di belakang perkampungan) (AlBustomi).

Leuweung Larangan (sebelah timur) merupakan hutan yang terlarang untuk diinjak oleh siapa pun, khususnya warga Kampung Naga di samping itu diyakini sebagai tempat para dedemit. Perkampungan tempat mereka hidup dan bercocok tanam di tengah-tengah, dan Leuweung Keramat (tempat nenek moyang mereka dimakamkan) yang ada di sebelah barat. Posisi perkampungan tidak secara langsung berhubungan dengan kedua hutan tersebut. Leuweung Larangan dibatasi oleh sebuah Sungai Ciwulan, sedangkan Leuweung Keramat dibatasi masjid, ruang pertemuan dan Bumi Ageung (tempat penyimpanan harta pusaka). ${ }^{1}$

${ }^{1}$ Pembatas "wilayah" tersebut memilik fungsi sosial dan kepercayaan yang sangat penting. Pertama, Bumi Ageung, yang terletak di paling atas kampung itu merupakan pusatnya yang sangat dikeramatkan. Pengurusnya harus seorang perempuan yang sudah tidak haid lagi. Tidak boleh seorang pun masuk ke dalam rumah tersebut, kecuali orang-orang yang dituakan (sesepuh). Di dalamnya tersimpan barangbarang yang yang dianggap keramat seperti senjata kuno, tombak. Kedua, mesjid yang digunakan mereka untuk beribadah. Ketiga, bale patemonan (ruang pertemuan) tempat melakukan upacara adat yang biasa mereka lakukan secara bersama-sama. Ketiga bangunan
Pola perkampungan demikian membangun kosmologi ruang: atastengah-bawah; atau baik-netral-buruk. Leuweung Larangan di arah timur dan Leuweung Keramat di arah barat sebagai sumber kekuatan sakral kehidupan keseharian mereka. Leuweung Larangan sebagai wilayah chaos, tempat semua dedemit dan roh jahat berada. Leuweung Karamat berada di sebelah barat adalah sumber kebaikan; masjid dan harta pusaka menjadi penghubung untuk mengalirkan kesakralan ke arah barat.

Leuweung Keramat dan Bumi Ageung yang berada di bagian barat masjid, di posisi kiblat, secara simbolis menunjukkan negosiasi ajaran Islam dan tradisi lokal. Menghadap ke kiblat berarti membayangkan penghadapan pada Kabah yang harus melalui penghadapan terhadap harta pusaka dan hutan keramat. Keinginan mendapatkan kesakralan Kabah didahului oleh penghubungan diri terhadap nenek moyang yang dikuburkan di Leuweung Keramat. Kosmologi ruang seperti ini barangkali yang menjadi dasar penolakan mereka terhadap warganya yang telah berhaji. Berhaji berarti berziarah secara langsung ke makam Orang Suci. Yang berhaji telah secara langsung berhubungan karena itu tak lagi membutuhkan kiblat yang dibungkus Bumi Ageung dan Leuweung Keramat (Al-Bustomi).

Melihat komposisi dan kedudukan Bumi Ageung tersebut memperlihatkan garis kosmologis yang tegas, yaitu bahwa seluruh rumah

tersebut seolah-olah mengelompok di tengah perkampungan dikitari oleh kelompok perumahan . 
berpusat pada Bumi Ageung dan Bumi Ageung berhubungan atau berpusat pada Leuweung Keramat, tempat nenek moyang atau makam para Karuhun.

Pandangan kosmologis yang menempatkan manusia (bumi tempat manusia berada) dalam impitan antara yang sakral (Leuweung Keramat) dan yang chaos (Leuweung Larangan), telah memposisikan manusia di antara dua keadaan tersebut. Hal tersebut tampak pada pandangan mereka tentang kosmologi waktu, yang secara umum dibagi dua, yaitu waktu nahas (tidak baik) dan waktu hade, baik. Keadaan kehidupan (dunia) manusia yang terimpit antara Leuweung Larangan (kebaikan, Yang Sakral) dan Leuweung Keramat (Ketidakbaikan, Yang Chaos) tersebut mengharuskan manusia untuk teliti dan hati-hati dalam menjalani kehidupan karena kedua dunia yang mengimpit tersebut telah pula mempengaruhi waktu kehidupan manusia, waktu baik dan waktu tidak baik.

Penduduk di Kampung Naga menganggap rumah merupakan bagian yang tidak terpisahkan dari konsep kosmologinya. Yakni adanya pandangan terhadap dunia atas dan dunia bawah atau pandangan tentang makro, dunya badag dan mikro, dunya leutik, lembut sesuai dengan nilai-nilai yang berlaku dalam kehidupan mereka sehari-hari. Rumah atau imah merupakan suatu menifestasi atau identik dengan dunia yang lebih besar (hubungan makro-mikro - makro kosmos). Rumah adalah penampung diri, rabi, keluarga dan keturunan. Rumah menjadi pusat datangnya seluruh pancaran rasa, karsa, karya dan yasa. Oleh karena itu segala sesuatu yang berhubungan dengan rumah dianggap sakral. Hal tersebut jelas tampak pada berbagai konsep ruang dalam rumah dan kesatuannya dengan lingkungan (Adimihardja,1986:52).

Rumah orang Naga mempunyai 3 (tiga) klasifikasi, yaitu dua klasifikasi yang bertentangan satu dengan yang lainnya dan sebuah klasifikasi lain yang bersifat netral; dengan kata lain rumah dibagi dalam tiga daerah yang jelas. Pembagian daerah tersebut yang diamati dari segi fungsinya ialah ruang yang dianggap suci, ruang yang tidak dianggap suci, dan ruang yang dianggap netral. Daerah yang dianggap netral itu adalah ruangan di antara kedua daerah tersebut. Ruang yang merupakan daerah netral dapat digunakan bersama, baik oleh wanita maupun laki-laki tetapi kadang-kadang juga digunakan hanya untuk wanita atau laki-laki saja.

Biasanya bagian belakang rumah, merupakan daerah wanita, di arah itu terletak goah (ruangan tempat menyimpan beras) dan dapur. Sedangkan di arah depan adalah daerah laki-laki. Laki-laki boleh masuk ke dapur, tetapi laki-laki dilarang bercakap-cakap di daerah dapur.

Daerah goah (ruangan tempat menyimpan beras) adalah ruang yang khusus untuk wanita. Laki-laki dilarang sama sekali masuk ke daerah (wilayah) ini. Isi goah adalah beras yang disimpan dalam padaringan dengan dikelilingi oleh berbagai macam sesajen, yang diperuntukan bagi Dewi Sri. Biasanya sasajen itu dibuat oleh wanita.

Ruang tempat menerima tamu biasa disebut tepas, meskipun diperuntukan bagi laki-laki namun 
kadang-kadang wanita juga boleh duduk di bagian ini. Namun, pada ruang (wilayah) yang biasa digunakan untuk bekerja pria jarang sekali wanita masuk. Bagian depan rumah ini (tepas) pada orang-orang Kampung Naga umumnya bersifat terbuka, tanpa dinding penyekat.

Upacara selamatan yang bersifat pribadi, biasanya di kalangan orangorang Kampung Naga di lakukan diruang (wilayah) tengah rumah (tengah imah), yang merupakan suatu ruangan yang terbuka untuk digunakan bagi semua anggota keluarga, baik lakilaki maupun wanita (daerah netral).

Sebagaimana dikemukan di atas, agaknya dalam konsep pandangan hidup orang-orang Kampung Naga, dapat dikemukakan bahwa pembagian ruang-ruang dalam rumah merupakan manifestasi dari kehidupan manusia itu sendiri dalam alam jagat raya ini. Sebuah rumah ditata berdasarkan konsep kategorisasi dari laki-laki dan wanita. Bagian depan rumah merupakan daerah laki-laki (tepas), sedangkan bagian belakang rumah (dapur dan goah) merupakan daerah wanita. Kamar tidur (pangkeng) dan tengah imah merupakan sepintas tampak sebelah kanan, kalau diamati dengan menggunakan konsep pembagian dua, sebenarnya termasuk daerah wanita, meskipun laki-laki (suami wanita tersebut dapat masuk ke kamar tidur itu), tetapi bagi laki-laki lain yang bukan suami dari wanita tersebut tidak diperkenankan masuk ke dalam kamar tidur itu. Sedangkan tengah imah memang merupakan daerah yang netral siapa saja yang dapat menggunakan kamar itu untuk bercakap-cakap atau bisa juga digunakan untuk kamar tidur anak-anak atau saudara yang ikut menginap di rumah tersebut. Biasanya kamar tidur itu terletak agak menyudut dari arah kamar tengah dan secara struktural letaknya agak menjauh dari goah dan ruang/kamar yang biasa digunakan untuk tempat pria bekerja.

\section{PENUTUP}

Konsep Tritangtu di Bumi merupakan rucita kepemimpinan masyarakat Sunda yang sangat tua. Embaran-embaran mengenai Tritangtu di Bumi ini ditunjang atau didasarkan pada naskah-naskah Sunda Buhun dan perikehidupan masyarakat kampung adat yang kini masih dapat kita saksikan salah satunya di Kampung Naga. Sementara itu, lembaran naskah yang memuat rucita Tritangtu di Bumi dapat ditelusuri pada naskah Siksa Kanda ng Karesian (1518), Carita Parahyangan (1580), dan Sewekadarma (masih abad ke-15).

Secara rinci Tritangtu di Bumi terdiri atas 3 (tiga) unsur yaitu: raja/ratu (prabu), rama, dan resi. Kekuatan Tritangtu terletak pada kekukuhan atau keteguhannya pada masing-masing unsur. Tidak ada diantara ketiga unsur tersebut saling berebut kekuasaan, tetapi masingmasing berjalan pada tempatnya sesuai dengan kapasitas dan profesialismenya masing-masing. Tujuannya adalah untuk menyentosakan pribadi (seseorang). Ia harus sentosa bagaikan raja, ucapannya harus dapat dipegang bagaikan petuah para tetua (rama), sedangkan budinya haruslah bagaikan budi seorang resi.

Tritangtu di Bumi adalah sistem kepemimpinan Sunda secara tradisional, yaitu sistem kepemimpinan 
yang dilakukan oleh tiga orang (Rama Resi - Prabu). Meskipun tidak sama persis, karena telah mengalami perubahan istilah dan ada sedikit perbedaan dengan aslinya, sistem ini pada saat ini masih dipertahankan dan dijalankan oleh warga Kampung Naga. Sistem organisasi pemerintahan Kampung Naga yang terdiri atas tiga perangkat, yaitu Kuncen, Lebe dan Punduh telah mengindikasikan penggunaan konsep Tritangtu di Bumi. Di samping itu, penerapan Tritangtu di Bumi tidak terbatas dalam sistem pemerintahan saja, tetapi juga telah merambah ke bidang kosmologi dan tata letak perkampungan.

Selanjutnya, guna memahami lebih mendalam mengenai peran tritangtu pada masyarakat Sunda tidak ada salahnya disarankan untuk melakukan 2 (dua) hal berikut. Penelusuran atas sejumlah kampung adat secara integral dan terpadu dari berbagai aspek kehidupan sosial budaya, termasuk sejarah di dalamnya tidak menutup kemungkinan akan memperjelas peranan tritangtu sesungguhnya.

Dalam cakupan lebih luas konsep Tritangtu di Bumi adalah konsep dasar dari berbagai sistem dan subsistem budaya Sunda. Setiap budaya (Sunda) nyaris tidak bisa dilepaskan dengan konsep yang dimaksud. Oleh karena itulah, upaya penggalian dan penelusuran Tritangtu hakikatnya menelusuri benang merah kebudayaan Sunda yang terputus selama ini. Dengan kata lain, konsep tritangtu dapat disarankan untuk dijadikan media dalam memahami kearifan dan nilai filosofis yang terkandung pada sebuah produk budaya Sunda.

\section{DAFTAR PUSTAKA}

Adimihardja, Kusnaka dkk. 1984.

Sistem Kepemimpinan di dalam Masyarakat Pedesaan Daerah Jawa Barat. Depdikbud Ditjen Kebudayaan Direktorat Sejarah dan Nilai Tradisional 1986.

Kesadaran Budaya Tentang Ruang Pada Masyarakat di Daerah Jawa Barat. Depdikbud Ditjen Kebudayaan Direktorat Sejarah dan Nilai Tradisional

Ahman Sya,M,dkk. 2008.

Sejarah Kampung Naga. Bandung: Dinas Kebudayaan dan Pariwisata Provinsi Jawa Barat Balai Pengembangan Kemitraan dan Pelatihan Tenaga Kepariwisataan.

Al-Bustomi, Ahmad Gibson. Kamis, 30 Januari 2003.

Islam-Sunda Bersahaja di Kampung Naga .Pikiran Rakyat,

Ayatrohaedi. 2002.

Kepemimpinan Dalam Masyarakat Sunda Berdasarkan Naskah. Balai Kajian Sejarah dan Nilai Tradisional Bandung.

1987.

Masyarakat Sunda Sebelum

Islam: Data Naskah. Laporan penelitian untuk Lembaga Penelitian Universitas Indonesia. 2001.

Nganjang $k a \quad$ Kalanggengan. Makalah disampaikan pada Konferensi Internasional Budaya Sunda. Bandung 
Asal usul Kebudayaan dan Perkembangan. Direktorat Sejarah dan Nilai Tradisional Dirjen Kebudayaan Depdikbud.

Djati Sunda, Anis.2002. (Makalah)

Teuleu Tangtu Kepemimpinan Tradisional Masyarakat Adat Urang Rawayan dan Pancer Pangawinan. Balai Kajian Sejarah dan Nilai Tradisional Bandung.

Danasasmita, Saleh. 1984.

Rintisan Penelusuran Masa Silam Sejarah Jawa Barat, 4 jilid. Bandung: Proyek Penerbitan Sejarah Jawa Barat.

Danasasmita, Saleh dan Anis Djatisunda. 1986.

Kehidupan Masyarakat Kanekes. Bandung: Bagian Proyek Penelitian dan Pengkajian Kebudayaan Sunda (Sundanologi) Ditjen $\mathrm{Ke}$ budayaan Depdikbud

Danasasmita, Saleh dkk. 1987.

Sewakadarma, Sanghyang Siksakandang Karesian, Amanat Galunggung: Transkripsi dan Terjemahan. Bandung: Bagian Proyek Penelitian dan Pengkajian Kebudayaan Sunda (Sundanologi) Ditjen Kebudayaan Depdikbud

Garna, Judistira .1993.

Budaya Daerah Sebagai Sumber Daya Dalam mengatasi arus modernisasi (makalah). Direktorat Sejarah dan Nilai Tradisional Ditjen Kebudayaan Balai Kajian Sejarah dan Nilai Tradisional. Depdikbud
Maria, Siti dkk. 1995.

Sistem Keyakinan pada Masyarakat Kampung Naga dalam Mengelola Lingkungan Hidup (Studi tentang Pantangan dan Larangan). Jakarta: Proyek Pengkajian dan Pembinaan Nilai-nilai Budaya Direktorat Sejarah dan Nilai Tradisional Dirjen Kebudayaan

Murniatmo G. et al. (1987).

Kehidupan Sosial Budaya Orang Naga, Salawu Tasikmalaya Jawa Barat. Ditjen Kebudayaan Balai Kajian Sejarah dan Nilai Tradisional, Yogyakarta.

Maryaeni, 2005.

Metode Penelitian Kebudayaan. Jakarta: Bumi Aksara.

Sucipto, Toto. 2005,

Masyarakat Adat, Kampung Adat, dan Kampung Khas. Balai Kajian Sejarah dan Nilai Tradisional Bandung.

Suhandono, Soni dkk. 1996.

Etnobotani orang seNaga Tasikmalaya Jawa Barat: Suatu telaah Pemanfaatan Sumberdaya Hayati Tumbuhan. Bandung: ITB.

Sumamihardja, A. Suhandi. 1984.

Organisasi dan Struktur Sosial Masyarakat Sunda. Jakarta: Girimukti Pasaka. 1991.

Pola Hidup Masyarakat Indonesia. Bandung: Fasa Unpad 1991/1992.

Kesenian, Arsitektur Rumah dan Upacara Adat Kampung Naga Jawa Barat. Depdikbud Proyek 
Pembinaan Media Kebudayaan Kamus

Ditjen Kebudayaan.

Kamus Umum Basa Sunda. 1995. LBSS. Bandung: Tarate

Umsari, Oyon Sofyan dkk. (1985/ 1986).

Bahasa Sunda Kampung Naga. Depdikbud Proyek Penelitian Bahasa dan Sastra Indonesia dan Daerah Jawa Barat.

Ensiklopedi Nasional Indonesia (ENI).1991. Jakarta: Cipta Adi Pustaka

http://dienyyusuf.com/2008/08/20/isla m-sunda-bersahaja-di-kampungnaga/ 